\title{
Chiropractic approach to the management of children
}

\author{
Sharon A Vallone*+1,2,3, Joyce Miller ${ }^{\dagger 4}$, Annica Larsdotter ${ }^{5}$ and Jennifer Barham-Floreani ${ }^{6}$
}

\begin{abstract}
Background: Chiropractic (Greek: done by hand) is a health care profession concerned with the diagnosis, treatment and prevention of disorders of the neuromusculoskeletal system and the effects of these disorders on general health. There is an emphasis on manual techniques, including joint adjustment and/or manipulation, with a particular focus on joint subluxation (World Health Organization 2005) or mechanical lesion and restoring function. The chiropractor's role in wellness care, prevention and treatment of injury or illness is based on education in anatomy and physiology, nutrition, exercise and healthy lifestyle counseling as well as referral to other health practitioners. Depending on education, geographic location, scope of practice, as well as consumer preference, chiropractors may assume the role of primary care for families who are pursuing a more natural and holistic approach to health care for their families.
\end{abstract}

Objective: To present a perspective on current management of the paediatric patient by members of the chiropractic profession and to make recommendations as to how the profession can safely and effectively manage the paediatric patient.

Discussion: The chiropractic profession holds the responsibility of ethical and safe practice and requires the cultivation and mastery of both an academic foundation and clinical expertise that distinguishes chiropractic from other disciplines.

Research into the effectiveness of chiropractic care for paediatric patients has lagged behind that of adult care, but this is being addressed through educational programs where research is now being incorporated into academic tracks to attain advanced chiropractic degrees.

Conclusion: Studies in the United States show that over the last several decades, chiropractors are the most common complementary and alternative medicine providers visited by children and adolescents. Chiropractors continue to seek integration with other healthcare providers to provide the most appropriate care for their paediatric patients.

In the interest of what is best for the paediatric population in the future, collaborative efforts for research into the effectiveness and safety of chiropractic care as an alternative healthcare approach for children should be negotiated and are welcomed.

\section{Background}

Chiropractic (Greek: done by hand) is a health care profession concerned with the diagnosis, treatment and prevention of disorders of the neuromusculoskeletal system and the effects of these disorders on general health. There is an emphasis on manual techniques, including joint adjustment and/or manipulation, with a particular focus on joint subluxation (World Health Organization 2005)

\footnotetext{
* Correspondence: svallonedc@aol.com

1 Private Practice, Connecticut, USA

+ Contributed equally

Full list of author information is available at the end of the article
}

or mechanical lesion and restoring function [1]. The chiropractor's role in wellness care, prevention and treatment of injury or illness is based on education in anatomy and physiology, nutrition, exercise and healthy lifestyle counseling as well as referral to other health practitioners. Depending on education, geographic location, scope of practice, as well as consumer preference, chiropractors may assume the role of primary care for families who are pursuing a more natural and holistic approach to healthcare for their families [2]. In this role, they may also provide "well child" care, monitoring growth and development. 
The purpose of this paper is to present a perspective on current management of the paediatric patient by members of the chiropractic profession and to make recommendations as to how the profession can safely and effectively manage the paediatric patient.

\section{Discussion}

\section{Use of Chiropractic by Children}

According to a report published in 2000 by Lee, $\mathrm{Li}$ and Kemper, the number of children visiting chiropractors was substantial and increasing [3]. A 2007 study by National Center for Health Statistics showed that the most common provider-based complementary and alternative therapy used by children in the United States was chiropractic or osteopathic manipulation [4]. Other recent studies in the United States show that approximately $14 \%$ of chiropractic patients are children under 18, and that chiropractors are the most common complementary and alternative medicine (CAM) providers visited by children and adolescents [5]. In 2007, Jean and $\mathrm{Cyr}$, in a survey of paediatric patients in an outpatient facility, found that $19 \%$ of the families sought chiropractic care for their children [6]. Carlton, Johnson and Cunliffe reported on the factors influencing parents' decisions to choose chiropractic care by surveying families with children ages 5-11 years in a typical county in the United Kingdom. The results indicated that parents who already used chiropractors were more likely to take their children to the chiropractor, but that the overall utilization of CAM was most influenced by family physician and friends [7].

\section{Chiropractic Education in Pediatrics}

Chiropractic college coursework has included paediatrics for the last several decades. In 1998, Coulter stated that the average hours of education in US chiropractic colleges assessed was 15 hours for paediatrics [8] in the total chiropractic curriculum which includes a minimum of 4,200 hours of classroom, laboratory and clinical experience $[9,10]$.

All chiropractic colleges' undergraduate courses in paediatrics recognize the unique anatomy and physiology of the paediatric patient. In turn, they promote the understanding that modification of evaluation and therapeutic techniques is required, thus preparing graduating chiropractors to work with their patient from birth through end of life. Chiropractic clinical education prepares the student to assess and manage (or co-manage as appropriate) the paediatric patient with a musculoskeletal problem.

As the profession grew, specialty interest groups were founded amongst national associations in the US (International Chiropractors Association, ICA, and American Chiropractic Association, $\mathrm{ACA}$ ) as well as by private indi- viduals [11-13]. Postgraduate education became available in both private entrepreneurial and academic venues. Academic venues offered by or sponsored by chiropractic colleges included individual postgraduate educational seminars and certification courses of approximately 100 to 120 hours. One such certification has, in the past, been offered by both the ICA Council on Chiropractic and the Anglo European Chiropractic College. Currently, this one-year certification program continues to be offered by the privately held International Chiropractic Paediatric Association (ICPA).

This one year certificate program may serve as the first year of study of the more advanced three year programs that confer diplomate status. For example, the International College of Clinical Chiropractic's program [11] offered in conjunction with the post graduate departments of chiropractic colleges like Palmer College of Chiropractic, New York College of Chiropractic and the New Zealand College of Chiropractic, consists of 360 classroom hours and includes required papers and annual exams before the candidates are eligible to sit for the board examination to qualify them for the Diplomate in Clinical Chiropractic Pediatrics. The International Chiropractic Paediatric Association (ICPA) also offers a diplomate program and testing is administered through the Academy of Chiropractic Family Practice [14].

In the European Union, there are currently two institutions offering a Masters in Science (MSc) with a specialty in paediatrics. These are AngloEuropean College of Chiropractic in conjunction with Bournemouth University and McTimoney Chiropractic College in conjunction with the University of Wales $[15,16]$.

\section{What Types of Cases Present to the Chiropractor?}

The age range of paediatric patients visiting chiropractic clinics ranges from premature infants to adolescents. Besides those conditions traditionally classified as musculoskeletal (for example, torticollis, scoliosis, sprain/ strains and spinal pain), there are also musculoskeletal presentations that include a somatovisceral component including, but not limited to, persistent crying and feeding problems in infants (like difficulty breastfeeding, colic), sleep disruption, otitis media, enuresis, asthma, headaches, constipation, learning disorders and a variety of presentations on the autistic spectrum $[17,18]$.

\section{What is Chiropractic Management?}

Chiropractors should obtain a full history and perform a complete, age appropriate examination, based on the presenting clinical symptoms as well as the general condition of the patient (Appendix 1). Depending on the circumstances, a written and/or an oral interview about the chief complaint, its history and a survey of systems may be completed, as well as performing an exam which may be 
Table 1: Serious Signs and Symptoms of Children that Require Immediate Medical Referral

\begin{tabular}{|c|c|}
\hline Symptom/Sign & Explanation/Implication \\
\hline Neonate & Since the health status of a neonate can change rapidly, any signs of illness require immediate referral. \\
\hline Lethargy & Absence of interaction, hypotonia and/or crying \\
\hline High Respiratory Rate & $\begin{array}{l}\text { Rapid or difficult respirations not related to activity; respiration rate }>60 \text { breaths/minute with rib } \\
\text { recession }\end{array}$ \\
\hline Blue Lips or Tongue & May indicate reduced blood oxygen level \\
\hline Dehydration & $\begin{array}{l}\text { Common sequel to diarrhea or vomiting. Dry mouth, sunken fontanelle, tenting skin, }<4 \text { wet nappies/ } \\
\text { diapers }(60-90 \mathrm{~mL} / 4-6 \mathrm{TBS}) \text {. Urine should be pale and mild smelling. }\end{array}$ \\
\hline Pain and Tenderness & $\begin{array}{l}\text { Child screams when touched or being moved; avoids being held. Sudden onset of groin pain in a boy may } \\
\text { be a sign of testicular torsion; episodic screaming in young children may be a sign of intussusception }\end{array}$ \\
\hline Tender Abdomen & Inability to tolerate $2 \mathrm{~cm}$ abdominal impression; bloated or rigid abdomen \\
\hline Inability to Walk & $\begin{array}{l}\text { Refusal or inability to walk in child who previously was walking (or crawling); development of a limp } \\
\text { requires attention }\end{array}$ \\
\hline Bulging Fontanelle & Evident bulge and rigidity in anterior fontanelle in a quiet child in an upright position \\
\hline Stiff or Rigid Neck & $\begin{array}{l}\text { Refusal/inability to look toward their toes or at a toe placed on their chest may be an early sign of } \\
\text { meningitis; very young infants may have meningitis with no obvious signs of neck stiffness }\end{array}$ \\
\hline Petechiae & $\begin{array}{l}\text { Purple or blood-red spots on the skin that do not blanch with pressure may be a sign of bloodstream } \\
\text { infection. Exclude bruises that have an explanation }\end{array}$ \\
\hline High Fever & $\begin{array}{l}\text { Referral for consult: Neonates ( }<28 \text { days): } \geq 38 \mathrm{C}(100 \mathrm{~F}) ; 28-90 \text { days }>38 \mathrm{C} \text { with signs of toxicity or incessant } \\
\text { crying; } 91-36 \text { months: }>39 \mathrm{C}(102.2 \mathrm{~F}) \text { and signs of toxicity [58]. }\end{array}$ \\
\hline Drooling & $\begin{array}{l}\text { Sudden onset of drooling not associated with teething, especially when associated with difficult } \\
\text { swallowing, may be a sign of epiglottal or pharyngeal infections }\end{array}$ \\
\hline
\end{tabular}

comprehensive or regional, with a more detailed follow up after the acute situation has been assessed and addressed. A comprehensive description of this complete intake and examination is beyond the scope of this paper. But it is important to emphasize that the clinician must carefully discern whether an infant is ill by physical examination (including temperature, pulse, respiration rate and effort, pallor, muscle tone and irritability or lethargy) and observation of any of the signs of illness of infancy (Table 1). Appropriate referral for co-treatment or alternative treatment should be made. Additionally, growth should be plotted and interpreted by using growth charts [19]. There should also be clear evidence that there are no red flags prior to accepting a paediatric case.

Once a child's condition is diagnosed and the condition is considered by the clinician to be potentially responsive to chiropractic care, parental permission is obtained and chiropractic treatment is administered.

An appropriate management plan should be brief and take into account the condition, age and size of the child, and it should be clear that intervention is affecting change ahead of the natural resolution history of the disorder. The clinician should demonstrate a clear understanding of the case, and should communicate with the parent in a manner which allays their anxiety. The clinician should obtain written evidence of receipt of permission to examine and treat the infant or child by a parent who is able to consent. Contra-indications to both treatment and types of treatment are outlined in Table 2.

Chiropractic management of paediatric patients may include advice about nutrition and exercise, in-clinic rehabilitation procedures, age appropriate paediatric 
Table 2: Absolute and Relative Contraindications to Manual Therapy

\begin{tabular}{|c|c|}
\hline \multicolumn{2}{|r|}{ ABSOLUTE CONTRAINDICATIONS } \\
\hline Indication & Explanation \\
\hline $\begin{array}{l}\text { Withdrawal of consent by } \\
\text { the parent or child }\end{array}$ & Potential for litigation \\
\hline $\begin{array}{l}\text { Hypermobility of the joints } \\
\text { of the child }\end{array}$ & Increased flexibility of joint structures and less muscular resistance than the adult \\
\hline $\begin{array}{l}\text { Long-lever and high force } \\
\text { manual procedures }\end{array}$ & Anatomically immature: no joint "lockup." \\
\hline $\begin{array}{l}\text { Occipito-atlantal \& } \\
\text { Atlanto-axial instability }\end{array}$ & $\begin{array}{l}\text { Common in children with Down Syndrome, Juvenile Rheumatoid Arthritis, Marquio's, Klippel-Feil } \\
\text { Syndrome }\end{array}$ \\
\hline Brain or spinal tumors & $\begin{array}{l}\text { Potential of neurologic damage or vascular compromise by the introduction of specific or non-specific } \\
\text { force due to the pathophysiology or anatomical position of the tumor; } \\
\text { immediate referral to appropriate healthcare provider }\end{array}$ \\
\hline $\begin{array}{l}\text { Active metaphyseal } \\
\text { growth tissue }\end{array}$ & $\begin{array}{l}\text { Zone of provisional calcification- the transitional region between cartilage and newly formed } \\
\text { metaphyseal bone is subject to separation and avascular necrosis when subject to force }\end{array}$ \\
\hline \multicolumn{2}{|r|}{ RELATIVE CONTRAINDICATIONS/Need for caution } \\
\hline Cervical Spine adjustments & $\begin{array}{l}\text { Reduce the incidence of potential adverse event by refraining from over treating the sensitive structures } \\
\text { of the cervical spine }\end{array}$ \\
\hline $\begin{array}{l}\text { Down Syndrome or other } \\
\text { congenital anomalies }\end{array}$ & If you see an anomaly in one region, be suspicious of anomalies elsewhere. \\
\hline $\begin{array}{c}\text { Recent upper respiratory } \\
\text { tract virus }\end{array}$ & Potential for inflammatory disruption to the atlanto-axial joint \\
\hline $\begin{array}{l}\text { Symptoms and signs } \\
\text { incongruous with } \\
\text { palpatory findings. }\end{array}$ & $\begin{array}{l}\text { Diagnosis requires corroboration of signs and symptoms with exam findings (including palpatory } \\
\text { findings). When they are incongruous, further diagnostic studies should be ordered to rule out any } \\
\text { potentially serious underlying pathology. }\end{array}$ \\
\hline $\begin{array}{l}\text { History of sleep-disorder in } \\
\text { infants }<12 \text { weeks of age }\end{array}$ & Watchful waiting first 12 weeks (rule out Arnold Chiari Syndrome) \\
\hline $\begin{array}{l}\text { Inversion of neonate or } \\
\text { young infant }\end{array}$ & $\begin{array}{l}\text { Relative contraindication secondary to neonatal circulation and clotting factors, respiratory distress, } \\
\text { cranial and cervical birth trauma, undiagnosed perinatal or postnatal stroke, undiagnosed hip dysplasia. }\end{array}$ \\
\hline
\end{tabular}

manipulation (modified from adult procedures based on paediatric anatomy) and soft tissue techniques and/or referral to another health provider.

\section{What type of response to care is typical?}

If a chiropractor determines that a mechanical lesion is responsible for the child's symptoms, chiropractors typically address this with manual therapy. Based on the authors' experience, symptoms of this nature would be expected to respond within approximately three to six treatments, depending on the duration of the problem.

After infancy, functional problems are more easily diagnosed with close observation as well as verbal and physical clues from the patient and the parents. Parents should report notable and significant improvement after a few treatments with full recovery shortly thereafter in routine cases. Long-term, complex, and difficult cases would typ- 
ically require longer-term care and the potential for additional treatments or co-management with other healthcare professionals.

Children with physical or neurologic disabilities may also require more extensive treatment. Often, as demonstrated anecdotally in the academic clinical setting or over the years at facilities like Kentuckiana Children's Center in Louisville, Kentucky, United States [20], when chiropractic treatment is provided in collaboration with other healthcare professionals (nutritionists, occupational therapists, physical therapists, art and recreational therapists, etc.), many children demonstrate improved development or a more consistent maintenance of their quality of life.

\section{Communication and collaboration benefits patients, healthcare providers and overburdened health care systems}

In reviewing the literature over the last decade, CAM health care providers, including chiropractors, have made sufficient inroads into paediatric healthcare to warrant the scrutiny of leaders in the field of conventional western medicine. Published papers explore everything about CAM from the economics [21-24] and utilization [25-31], to review of effectiveness for specific conditions [32-37] as well as ethics, policy and malpractice risks $[38,39]$. Communication between parent and healthcare practitioner is a particular concern expressed in a number of these scholarly papers. Providers report that parents often fail to communicate that their children are receiving CAM therapies when they visit their offices for routine wellness visits (visits where the GP or pediatrician monitors normal growth and development, administers required immunizations, etc), when the child presents in an emergency room in crisis or when the child is receiving ongoing care for chronic illnesses. It is unknown whether this failure to communicate is due to fear of the provider's censure, a failure to realize significance of the information to the healthcare provider or an unintentional omission. This may be perceived as increasing the malpractice risk for the practitioner when the clinician is administering therapeutic measures without being fully informed. One author suggests that collaborative care in a hospital setting might improve outcome in cases of comanagement [40].

\section{Where is the evidence?}

Careful scrutiny of the evidence for the efficacious treatment of a variety of common pediatric complaints demonstrates the need for more research in all fields. One of the most common afflictions of infants, excessive crying or infant colic, serves as an example of the paucity of evidence. Traditional Western medicine has failed to provide any safe, effective therapy for infant colic [41] or for other common complaints of infancy, such as the excessive crying, poor sleep habits (difficulty going to sleep and staying asleep) and sub-optimal feeding. The available evidence is limited about chiropractic therapy for any of these conditions [23]. However, there is also a lack of evidence about any other therapy for these conditions $[42,43]$.

There is some evidence that taking a colicky infant to a chiropractor will result in decreased crying [44]; it is not known whether this response is specific to paediatric manipulation or whether there may be multiple non-specific effects at play [19,45-47]. Currently two randomized trials, one in England and one in Denmark, are in process now to gather more definitive evidence on this issue. This evidence as it exists can be made available to the parents. It can also be explained that the recommendation for care made by the chiropractor is based on, not only the available evidence, but also his or her professional experience coupled with the low risks of adverse effects [48,49]. This makes a therapeutic trial of chiropractic care for infantile colic a viable alternative for the parents to consider when evaluating the full picture of available, effective treatments.

It is also imperative that in this same context of informed consent, the treating chiropractor must qualify him- or herself to the parents/patient as having mastered appropriate skills and fully evaluated the child (as outlined earlier), ruled out contraindications to chiropractic care and have made appropriate referrals before, or in addition to, providing chiropractic treatment.

As stated earlier, negative side effects of paediatric manipulation are rare and mild $[48,49]$. The risks of harm (from potential child abuse) coming to an inconsolable crying baby without intervention can be significant $[50,51]$. We therefore estimate that the risk/benefit ratio falls into the camp of a short (two week) trial of chiropractic treatment until and unless evidence accumulates to show no effect of such treatment. Additional research should investigate whether this therapeutic contact with the chiropractor may have provided a safe haven for these families to vent the frustration and difficulties of dealing with a crying baby, reducing the risk of injury to the infant by a frustrated parent.

\section{How safe is manual therapy for the paediatric patient?}

Although manual therapy is the treatment identified with chiropractors, chiropractic is a profession, not a therapy. Manual therapy is provided by many other types of clinicians including osteopaths, medical doctors, physiotherapists, cranial sacral therapists and multiple alternative practitioners. This creates a problem when reviewing the safety record of manual therapy. A recent systematic review of the safety record of manual therapy for paediatric patients showed that there were 14 reported adverse 
events in 41 years [44]. Nearly half of those injuries were caused by non-chiropractic clinicians who represent a small minority of those performing manual therapy. In fact, chiropractors provide $94 \%$ of manipulative care in the United States [52]. Any adverse event should be avoided, but any treatment able to effect positive change may put the patient at some risk. The evidence, so far, is that manual therapy for the paediatric patient, in the hands of a skilled chiropractor, has a very low risk.

Chiropractors are committed to gathering all data relative to risks. In the United Kingdom, there is a professionwide initiative called the Chiropractic Patient Incident Reporting and Learning System http://www.CPiRLS.org. This is an on-line forum on which chiropractors share all patient safety incidents, including paediatrics. It is used by all registered chiropractors in the United Kingdom. There is a similar system in place in Switzerland as well. The system for the European Chiropractic Union is currently in the guidelines stage. Prospective monitoring of all safety incidents is the way forward to track risks to treatment of the paediatric patient.

\section{Ethics and responsibility as practitioners}

Recently, a multidisciplinary panel of chiropractors was able to reach consensus regarding the chiropractic approach to the paediatric chiropractic patient "based on both scientific evidence and clinical experience". This demonstrated an effort on the part of the profession to establish standards to guide practising clinicians [53].

Research into the effectiveness of chiropractic care for paediatric patients has lagged behind that of adult care, but this is being addressed through educational programs where research is now being incorporated into academic tracks to attain advanced chiropractic degrees.

The responsibility of ethical and safe practice lies within the profession. This begins with an acknowledgement that it requires the cultivation and mastery of both an academic foundation and clinical expertise in the art, science and philosophy of chiropractic to distinguish the chiropractic profession from other disciplines. Chiropractic is a profession, not a technique and chiropractors are responsible for diagnosis and appropriate management of any case they accept.

For example, determining the necessity of care for the paediatric population is not necessarily justified by the usual criteria of specific objective measurements such as a level of impairment, pain or range of motion. The paediatric patient may be evaluated utilizing these traditional criteria but may also have other objective findings that support the necessity for chiropractic care like the presence or absence of infant reflexes or relative attainment of developmental milestones secondary to neurologic or motor impairment (feeding, sitting, crawling, etc). Therefore an understanding of child development is critical for treatment of a pediatric patient. If a clinician is not appropriately trained in evaluating or treating a child, then becoming acquainted with colleagues who are competent is strongly recommended. The chiropractor's responsibility goes beyond the application of chiropractic principles and practice, but also in the timely recognition of critical red flags and the need for referral for collaborative treatment to chiropractors or other appropriate healthcare professionals.

Amassing evidence for the effectiveness and safety of chiropractic care for children is gradually progressing, thanks to the dedication of academicians and clinicians around the world. Authors such as Hawk and Fallon $[54,55]$ have expounded on the challenges we face in attempting to develop ethical, safe and comprehensive models to study. It is important that the problems of infancy and children which cause suffering to children and families and use significant health care and community resources should be high on the list of conditions to investigate.

\section{Conclusion}

Studies in the United States show that over the last several decades, chiropractors are the most common CAM providers visited by children and adolescents. Chiropractors continue to seek integration with other healthcare providers to provide the most appropriate care for their paediatric patients.

In the interest of what is best for the paediatric population in the future, collaborative efforts for research into the effectiveness and safety of chiropractic care as an alternative healthcare approach for children should be negotiated and are welcomed.

\section{Appendix 1: Chiropractic Assessment of the Pediatric Patient $[56,57]$ History and Survey of Symptoms}

A focused history of the chief complaint should be age and situation-specific but a complete history (from gestation) should also be obtained. A complete history should include (but is not limited to):

- Parents' health history (including relevant genetic history)

- History of mother's previous and current pregnancies, including ante partum and intra partum events - Complete intervening health history of patient including illness, accidents, surgeries, hospitalizations, previous chiropractic or other therapies, concurrent diagnosis or intervention for presenting condition and the patient's response to care.

- Survey of systems involves reviewing responses to questions asked in an interview or in a detailed questionnaire which will reveal perceived or actual level of function of organ systems of the body. If using a ques- 
tionnaire, review questionnaire with the patient, parent(s) or guardian and record in patient notes.

\section{Assessment}

Growth, head circumference and gestational age:

- use age specific World Health Organization growth charts

\section{Vital signs:}

- Heart rate (blood pressure if appropriate to evaluate in a particular situation)

- Respiratory rate/temperature/pallor/skin turgor

Physical examination- appropriate for age and presenting clinical symptoms and general health of patient. To include (but not be limited to):

- Visual assessment for gross morphologic changes, discoloration, deformity, atrophy, etc.

- Auscultation chest (heart and lungs) and abdomen

- Palpation: cranium including fontanelles, lymph nodes, soft tissue, abdomen and skeletal structures

- Neurologic and orthopedic examination to include:

a. Reflexes (Infantile and Deep Tendon Reflexes)

b. Range of motion and joint integrity

c. Muscle mass, tone and strength

d. Integrity of sensory system (including sensory processing)

- Age appropriate developmental evaluation

- Large motor skills (ranging from antigravity muscular control to locomotion)

- Small motor skills (manual dexterity with simple and complex skills)

- Language (receptive and expressive)

- Cognition, demeanor and social skills

\section{Chiropractic Assessment:}

- Posture (appropriate to developmental age) and alignment of skeletal structures

- Pedal integrity (rule out pes planus, pes cavus, club foot, etc)

- Cranial and skeletal motion

- Soft tissue integrity, restriction, adhesion or fibrosis

\section{Competing interests}

The authors declare that they have no competing interests.

\section{Authors' contributions}

SAV originally conceived of the conceptual basis of the manuscript. SAV and $\mathrm{JM}$ shared the writing of the initial manuscript, and this was circulated amongst all authors for editing and revisions until the final manuscript was agreed upon. All authors took part in researching, editing and revising the manuscript on multiple occasions.

\section{Acknowledgements}

$S A V, J M, A L$ and JB would like to acknowledge those who generously contributed their time, information, clarification, inspiration and motivation to the authors including, but not necessarily limited to, Drs. Evalie Heath (Zimbabwe), Charmaine Korporaal (South Africa), Navine Haworth (Australia), Phillip Ebrall (Australia), Simon Floreani (Australia), Rosemary Keating (Australia), Sharyn Eaton (Australia), Brian Kelly (New Zealand), Sandra Leung (Hong Kong), Joanna Schultz (Canada), Chantal Pinard (Canada), Tone Tellefson-Hughes (United Kingdom), Christine Cunliffe (United Kingdom), Valérie Klingelschmitt (France),
Eileen Shull (United States) and Lora Tanis (Unites States). We thank Cheryl Hawk, DC, PhD, (United States) for her invaluable assistance in reviewing the manuscript.

\section{Author Details}

1Private Practice, Connecticut, USA, 2Kentuckiana Children's Center, Louisville, KY, USA, ${ }^{3}$ Post Graduate Faculty, International College of Chiropractic Pediatrics, Arlington, VA 22201, USA, ${ }^{4}$ Lead Tutor MSc Advanced Practice Paediatrics, Bournemouth University, UK, ${ }^{5}$ Private Practice, Sydney, Australia and 6 Private Practice, Melbourne, Victoria, Australia

Received: 19 December 2009 Accepted: 2 June 2010

Published: 2 June 2010

References

1. World Health Organization: WHO guidelines on basic training and safety in chiropractic. Geneva 2005 [http://www.who.int/medicines/areas/ traditional/Chiro-Guidelines.pdf].

2. Duenas R: United States Chiropractic Practice Acts and Institute of Medicine defined primary care practice. Journal of Chiropractic Medicine 2002, 1(4):155-170.

3. Lee A, Li H, Kemper KJ: Chiropractic care for children. Arch Pediatr Adolesc Med 2000, 154(4):401-407.

4. Barnes PM, Bloom BS: Complementary and alternative medicine use among adults and children: United States, 2007. Natl Health Stat Reports 2008, 12:1-24

5. Kemper KJ, Vohra S, Walls R: The use of complementary and alternative medicine in pediatrics. Pediatrics 2008, 122:1374-1386.

6. Jean $\mathrm{D}, \mathrm{Cyr} \mathrm{C}$ : Use of complementary and alternative medicine in a general pediatric clinic. Pediatrics 2007, 120:e138-e141.

7. Carlton P, Johnson I, Cunliffe C: Factors influencing parents' decisions to choose chiropractic care for their children in the UK. Clinical Chiropractic 2009, 12(1):11-22

8. Coulter ID, Adams A, Coggan P, Wilkes M, Gonyea M: A comparative study of chiropractic and medical education. Altern Ther Health Med 1998, 4(5):64-75

9. Coulter ID, Adams AH, Sandefur R: Chiropractic Training. In Chiropractic in the United States: Training, Practice and Research AHCPR Publication No. 98-N002; 1997:17-28.

10. Bureau of Labor Statistics - Chiropractors Occupational Outlook Handbook, 2010-11 Edition [http://www.bls.gov/oco/ocos071.htm].

11. ICA Council on Chiropractic Paediatrics, Postgraduate Education: Diplomate [http://www.icapediatrics.com/members-postgrad.php]

12. ACA Council on Chiropractic Pediatrics [http:// www.acapedscouncil.org/

13. International Chiropractic Pediatric Association [http://icpa4kids.com/ seminars/CertificationProgram.html]

14. The Academy of Chiropractic Family Practice, Academy Diplomates [http://www.chiropracticfamilypractice.org/diplomates.html]

15. Anglo-European Chiropractic College, MSc Advanced Chiropractic Paediatric Practice [http://www.aecc.ac.uk/cms/site/docs/ MSc\%20APP\%20Chiropractic\%20Paediatrics.pdf

16. McTimoney Chiropractic College, MSc Paediatrics [http:// www.mctimoney-college.ac.uk/page/ 65 MSc Chiropractic Paediatrics.html

17. Gotlib A, Rupert R: Chiropractic manipulation in paediatric health conditions - an updated systematic review. Chiropr \& Osteopat 2008, $16: 11$

18. Hawk C, Khorsan MA, Lisi AJ, Ferrance RJ, Willard Evans M: Chiropractic care for nonmusculoskeletal conditions: a systematic review with implications for whole systems research. J Altern Compl Med 2007, 13(5):491-512

19. UK-WHO Growth Charts; Early Years [http:// www.growthcharts.rcpch.ac.uk]

20. Barnes TA: Kentuckiana Children's Center: a 40 year history. Journal of Chiropractic Humanities 1997, 7(1):18-22

21. Eisenberg DM, Kessler RC, Foster C, Norlock FE, Calkins DR, Delbanco TI: Unconventional medicine in the United States: prevalence, costs, and patterns of use. NEng/ J Med 1993, 328:246-252.

22. Bellas A, Lafferty WE, Lind B, Tyree PT: Frequency, predictors, and expenditures for pediatric insurance claims for complementary and 
alternative medical professionals in Washington State. Arch Pediatr Adolesc Med 2005, 159:367-372.

23. Herman PM, Craig BM, Caspi O: Is complementary and alternative medicine [CAM] cost-effective? A systematic review. BMC Complement Altern Med 2005, 5:11.

24. Thomas KJ, Nicholl JP, Coleman P: Use and expenditure on complementary medicine in England: a population based survey. Complement Ther Med 2001, 9(1):2-11.

25. Spigelblatt L, Laine-Ammara G, Pless IB, Guyver A: The use of alternative medicine by children. Pediatrics 1994, 94:811-814.

26. Eisenberg DM, Davis RB, Ettner SL, Appel S, Wilkey S, Van Rompay M Kessler RC: Trends in alternative medicine use in the United States, 1990-1997: results of a follow-up national survey. JAMA 1998, 280:1569-1575

27. Ottolini MC, Hamburger EK, Loprieato JO, Coleman RH, Sachs HC, Madden $\mathrm{R}$, Brasseux C: Complementary and alternative medicine use among children in the Washington, D.C. area. Ambul Pediatr 2001, 1:122-125.

28. Loman DG: The use of complementary and alternative health care practices among children. J Pediatr Health Care 2003, 17:58-63.

29. South M, Lim A: Use of complementary and alternative medicine in children: too important to ignore. J Pediatr Child Health 2003, 38(8):573-574

30. Yussman SM, Ryan SA, Auinger P, Weitzman M: Visits to complementary and alternative medicine providers by children and adolescents in the United States. Ambul Pediatr 2004, 4:429-435.

31. Wilson K, Dowson C, Mangin D: Prevalence of complementary and alternative medicine use in Christchurch, New Zealand: children attending general practice vs. paediatric outpatients. NZ Med J 2007, 120(1251):39-47.

32. Armishaw J, Grant CC: Use of complementary treatment by those hospitalized with acute illness. Arch Dis Child 1999, 81(2):133-137.

33. Reznick M, Ozuah PO, Franco K, Coen R, Motlow F: Use of complementary therapy by adolescents with asthma. Pediatr Adolesc Med 2002, 156:1042-1044

34. Heuschkel R, Afzal N, Wuerth A, Zurakowski D, Leichtner A, Kemper K, Tolia $V$, Bousvaros A: Complementary medicine use in children and young adults with inflammatory bowel disease. Am J Gastroenterol 2002, 97:382-388

35. Hagen LE, Schneider R, Stephens D, Modrusan D, Feldman BM: Use of complementary and alternative medicine by paediatric rheumatology patients. Arthritis Rheum 2003, 49:3-6.

36. Johnston GA, Bilbao RM, Graham-Brown RA: The use of complementary medicine in children with atopic dermatitis in secondary care in Leicester. Br J Dermatol 2003, 149:566-571.

37. Sinha D, Efron D: Complementary and alternative medicine use in children with attention deficit hyperactivity disorder. J Pediatr Child Health 2005, 41:23-26.

38. Cohen MH, Kemper KJ, Stevens L, Hashimoto D, Gilmour J: Pediatric Use of complementary therapies: ethical and policy choices. Pediatrics 2005, 116:e568-e575.

39. Cohen MH, Kemper KJ: Complementary therapies in pediatrics: a legal perspective. Pediatrics 2005, 115:774-780.

40. McCann LJ, Newell SJ: Survey of pediatric complementary and alternative medicine use in health and chronic illness. Arch Dis Child 2006, 91:173-174

41. Underwood M: Treatment of infant colic. Int J Clin Pract 2009, 63(9):1267-1274.

42. Lucassen Pl, Assemdeft WJ, Gubbels JW, van Eiji JT, van Geldrop WJ, Neven AK: Effectiveness of treatment for infant colic: a systematic review. BrMed J 1998, 316(7144):1563-1569.

43. Garrison MM, Christakia DA: A systematic review of treatments for infant colic. Pediatrics 2000, 106:184-190

44. Hughes $\mathrm{S}$, Bolton J: Is chiropractic an effective treatment in infantile colic. Arch Dis Child 2002, 86(5):832-4.

45. Olafsdottir E, Forshei S, Fluge G, Markestad T: Randomized controlled trial of infantile colic treated with spinal manipulation. Arch Dis Child 2001, 84:138-141.

46. Wiberg JM, Nordsteen J, Nilsson N: The short-term effect of spinal manipulation in the treatment of infantile colic: a randomized controlled clinical trial with blinded observer. J Manipulative Physiol Ther 1999, 22:517-522.
47. Klougart N, Nilsson N, Jacobsen J: Infantile colic treated by chiropractors: a prospective study of 316 cases. J Manipulative Physiol Ther 1989, 12:281-288.

48. Vohra S, Bradley C, Johnston KC, Humphreys K: Adverse events associated with Paediatric spinal manipulation: a systematic review. Pediatrics 2007, 119:275-283.

49. Miller J, Benfield K: Adverse effects of spinal manipulative therapy in children younger than 3 years: a retrospective study in a chiropractic teaching clinic. J Manipulative Physiol Ther 2008, 31(6):419-423.

50. Agran PF, Anderson C, Winn D, Trent R, Walton-Haynes L, Thayer S: Rates of Paediatric injuries by 3-month intervals for children 0 to 3 years of age. Pediatrics 2003, 111:e683-692.

51. Lee C, Barr RG, Catherine N, Wicks A: Age-related incidence of publicly reported shaken baby syndrome cases: is crying a trigger for shaking? J Dev Behav Pediatr 2007, 28(4):288-293.

52. National Board of Chiropractic Examiners. Job Analysis of Chiropractic 2005 [http://www.nbce.org]

53. Hawk C, Schneider M, Ferrance RJ, Hewitt E, Van Loon J, Tanis L: Best practices recommendations for chiropractic care for infants, children, and adolescents: results of a consensus process. I Manipulative Physiol Ther 2009, 32(8):639-647

54. Hawk C, Long CR, Rowell RM, Gudavalli MR, Jedlicka J: A Randomized Trial Investigating a chiropractic manual placebo: a novel design using standardized forces in the delivery of active and control treatments. $J$ Alternative and Complement Med 2005, 11(1):109-17.

55. Fallon J: The Child Patient: A Matrix for Chiropractic Care. Journal of Clinical Chiropractic Pediatrics 2005, 6((3) Supplement):1-14

56. Davies NJ: Chiropractic pediatrics: a clinical handbook 1st edition. Sydney: Churchill Livingstone an imprint of Harcourt Publishing: 2000.

57. Fysh PN: Chiropractic care for the pediatric patient 1st edition. Virginia: International Chiropractic Association, Council on Chiropractic Pediatrics; 2002.

58. Baraff $L J$ : Management of fever without source in infants and children Ann Emerg Med 2000, 36(6):602-614.

doi: $10.1186 / 1746-1340-18-16$

Cite this article as: Vallone et al., Chiropractic approach to the management of children Chiropractic \& Osteopathy 2010, 18:16

\section{Submit your next manuscript to BioMed Central and take full advantage of:}

- Convenient online submission

- Thorough peer review

- No space constraints or color figure charges

- Immediate publication on acceptance

- Inclusion in PubMed, CAS, Scopus and Google Scholar

- Research which is freely available for redistribution 